\title{
FAKTOR-FAKTOR YANG MEMPENGARUHI POLA KONSUMSI SAYURAN PADA RUMAH TANGGA PETANI SAYURAN DI DESA SRIMAHI KECAMATAN TAMBUN UTARA KABUPATEN BEKASI
}

\author{
FACTORS AFFECTING CONSUMPTION OF VEGETABLE IN VEGETABLE FARMERS \\ HOUSEHOLD IN VILLAGE SRIMAHI, TAMBUN UTARA DISTRICT, BEKASI REGENCY
}

\author{
Azizah Fitria Wijayanti*, Trisna Insan Noor \\ Universitas Padjadjaran, Jl. Raya Bandung Sumedang KM. 21 \\ *E-mail: Azizahfitria87@gmail.com \\ (Diterima 10-1-2021; Disetujui 18-1-2021)
}

\begin{abstract}
ABSTRAK
Sayuran merupakan golongan pangan yang memiliki kandungan vitamin, mineral dan zat gizi lainnya yang dibutuhkan oleh tubuh manusia sehingga menyehatkan bagi tubuh. Kualitas konsumsi pangan golongan sayuran di Indonesia masih rendah dan kurang terdiversifikasi, masih didominasi pangan sumber karbohidrat, terutama dari padi -padian. Dengan adanya pandemi Covid- 19 membuat pola konsumsi masyarakat mengalami perubahan yang tadinya sangat konsumtif menjadi berkurang. Meluasnya penyebaran virus Covid -19, masyarakat khususnya petani dituntut untuk menjaga daya tahan tubuh mereka dengan lebih memperhatikan konsumsi sayuran. Penelitian ini bertujuan untuk mengetahui faktor-faktor yang mempengaruhi konsumsi sayuran pada rumah tangga petani sayuran. Penelitian dilakukan di Desa Srimahi, Kecamatan Tambun Utara, Kabupaten Bekasi pada bulan Oktober-November 2020. Jumlah sampel penelitian sebanyak 66 rumah tangga dengan responden penelitian adalah ibu rumah tangga. Penelitian ini menggunakan desain penelitian kuantitatif dengan metode survei. Metode analisis yang digunakan adalah menggunakan metode deskriptif dan analisis regresi logistik untuk mengetahui faktor- faktor yang mempengaruhi konsumsi sayuran. Hasil penelitian menunjukkan bahwa faktor-faktor yang mempengaruhi konsumsi sayur pada rumah tangga petani sayuran adalah pengetahuan gizi ibu, pendidikan ibu, dan pekerjaan ibu.
\end{abstract}

Kata Kunci: Pola Konsumsi, Sayuran, Faktor-Faktor yang Mempengaruhi Konsumsi Sayuran

\begin{abstract}
Vegetables are a food group that contains are vitamins, minerals and other nutrients that needed by the body for health. The quality of vegetable consumption in Indonesia is still low and less diversified, still dominated by food sources of carbohydrates, especially from grains. The Covid-19 pandemic has made people's consumption patterns change from being very consumptive to being reduced. With the spread of the Covid-19 virus, people, especially farmers, are required to maintain their immune system by paying more attention to vegetable consumption. This study aims to determine the factors that influence vegetable consumption in vegetable farmer households. The research was conducted in Srimahi Village, North Tambun District, Bekasi Regency in OctoberNovember 2020. The number of research samples was 66 households, with research respondents being housewives. The design used quantitative design with survey method. Data analysis used descriptive statistics with the logistic regression. The results showed that the factors that influenced vegetable consumption in vegetable farmer households were maternal nutritional knowledge, mother's education, and maternal occupation.
\end{abstract}

Keywords: Consumption Patterns, Vegetables, Factors That Affect Vegetable Consumption 


\section{PENDAHULUAN}

Pada akhir tahun 2019 dunia sedang mengalami wabah virus yang disebut dengan virus corona (Covid-19) dan telah menginfeksi hampir seluruh negara di dunia. Penyakit ini ditemukan di Wuhan, Hubei, China. Covid-19 ini merupakan suatu penyakit menular yang disebabkan oleh sindrom pernapasan akut. Penyakit ini menyebar dengan sangat cepat dan meluas hingga 188 negara di dunia, termasuk Indonesia.

Dalam memperlambat laju penularan dan penyebaran Covid - 19 di Indonesia, Presiden Joko Widodo menetapkan Peraturan Pemerintah ( PP ) Nomor 21 Tahun 2020 tentang tindakan pembatasan sosial berskala besar ( PSBB ). Hal- hal yang dibatasi selama PSBB berlangsung yaitu aktivitas di tempat kerja, kegiatan keagamaan, kegiatan di tempat atau fasilitas umum, kegiatan sosial budaya, sekolah dan operasional transportasi umum.

Diberlakukannya PSBB, tentunya akan mempengaruhi sektor-sektor yang berhubungan dengan mobilitas masyarakat sehari -hari. Terdapat beberapa sektor yang paling terdampak PSBB, yaitu sektor wisata, sektor manufaktur, sektor ekonomi, sektor transportasi, sektor sosial, sektor pangan, dan pertanian.

Selain itu, selama masa pandemi Covid-19 pola konsumsi masyarakat mengalami perubahan yang sebelumnya sangat konsumtif, sekarang menjadi berkurang. Hal tersebut merupakan suatu hal umum bagi masyarakat untuk beradaptasi dalam lingkungan yang serba terbatas. Kebutuhan pokok saat ini lebih dipentingkan oleh masyarakat untuk menunjang dalam bertahan hidup dengan jangka waktu yang lama (Hutauruk, 2020).

Konsumsi merupakan suatu penunjang untuk mengukur tingkat kesejahteraan rumah tangga. Konsumsi rumah tangga akan berbeda antara satu dengan lainnya dikarenakan kebutuhan mereka yang berbeda -beda (Akmal, 2003). Aspek yang dapat dijadikan suatu indikator dalam perubahan pola konsumsi adalah rumah tangga. Dalam rumah tangga, dapat dilihat bagaimana cara mereka untuk memenuhi kebuthannya diikuti dengan naik turunnya kemampuan daya beli yang akan berdampak pada perubahan pola konsumsi.

Dengan adanya virus Covid-19 ini mendorong masyarakat untuk meningkatkan imunitas tubuh serta 
mengonsumsi makanan yang bergizi dan beragam. Ketahanan pangan merupakan hal yang paling utama yang harus diperhatikan.

Cara yang dapat dilakukan untuk menjaga daya tahan tubuh, salah satunya yaitu dengan mengonsumsi buah dan sayur (Permana, 2020). Menurut Winarto (2004), sayur merupakan bagian utama dari dapat memberikan vitamin, mineral, serat, klorofil, air, oksigen, dan senyawa organik lain kepada tubuh.

Rachman dan Ariani (2008) menyatakan bahwa rata- rata kualitas konsumsi sayuran di Indonesia tergolong masih sangat rendah dan masih didominasi oleh pangan sumber karbohidrat, terutama dari padi -padian.

Pemenuhan kebutuhan sayuran merupakan upaya peningkatan kualitas kesehatan. Namun, hingga saat ini pemenuhan sayuran yang beragam, bergizi dan berimbang, aman masih belum terpenuhi terutama di masyarakat pedesaan. Karbohidrat masih merupakan kelompok pangan yang banyak dikonsumsi dan beras masih menjadi mayoritas untuk pangan pokok (Murdiati dan Amaliah, 2013).

Konsumsi sayuran di Indonesia masih sangat kurang dan masih jauh dari standar kecukupan sayuran dalam (gram) per hari, sesuai dengan anjuran FAO. Hal ini dapat terlihat dari kesadaran masyarakat Indonesia yang masih kurang dalam pemenuhan gizi seimbang.

Minimnya pengetahuan akan konsumsi makanan bergizi juga dapat dilihat pada masyarakat di pedesaan. Terdapat perbedaan tingkat konsumsi sayuran di perkotaan dan pedesaan dimana tingkat konsumsi sayur dan buah pada penduduk perkotaan cenderung lebih tinggi dibandingkan dengan pedesaan. Rendahnya tingkat konsumsi buah dan sayur, dapat menimbulkan sebuah masalah pada gangguan kesehatan. Sehingga konsumsi sayur perlu ditingkatkan baik dari segi kuantitas maupun kualitasnya (BPS, 2016).

Di daerah pedesaan masih banyak lahan untuk pertanian yang cukup luas dan banyak masyarakat pedesaan yang masih berprofesi sebagai petani. Salah satunya yaitu Kabupaten Bekasi yang merupakan daerah dengan penduduk mayoritas berprofesi sebagai petani. Kecamatan Tambun Utara adalah salah satu sentra produksi sayuran di Kabupaten Bekasi.

Hasil produksi sayuran di Kecamatan Tambun Utara masih cukup 
tinggi, seharusnya pola konsumsi sayuran juga harus seimbang dengan hasil produksi. Pola konsumsi masyarakat tidak menentu dan dapat berbeda serta berubah-ubah dari waktu ke waktu serta dari tempat yang satu ke tempat yang lain. Pola konsumsi pangan pada satu daerah dengan daerah yang lain akan berbeda-beda tergantung pada lingkungan, sumber daya, budaya, selera serta pendapatan pada daerah tersebut (Kementerian Perdagangan, 2013).

Di tengah pandemi seperti ini, kondisi kesehatan petani juga harus tetap terjaga agar terhindar dari paparan virus Covid-19. Kesehatan petani sangat berpengaruh terhadap kesejahteraan petani, yang harus terjamin agar dapat memaksimalkan kebutuhan pangan masyarakat Indonesia. Dengan begitu sektor pertanian akan tetap bertahan di masa pandemi seperti ini.

Dian (2019) menyatakan bahwa terdapat faktor-faktor yang dapat mempengaruhi jumlah konsumsi sayuran pada rumah tangga petani, diantaranya pendapatan rumah tangga, jumlah anggota rumah tangga, pendidikan ibu rumah tangga, ketersediaan sayuran, pengetahuan gizi ibu dan pekerjaan ibu rumah tangga.
Hal tersebut menarik untuk dikaji sehingga tujuan penelitian ini adalah mengetahui apa saja faktor-faktor yang dapat mempengaruhi konsumsi sayuran pada rumah tangga petani sayuran di Desa Srimahi Kecamatan Tambun Utara Kabupaten Bekasi.

\section{METODE PENELITIAN}

Penelitian dilaksanakan pada bulan Oktober-November 2020 di Desa Srimahi Kecamatan Tambun Utara Kabupaten Bekasi. Lokasi dipilih karena Kecamatan Tambun Utara termasuk daerah dengan produksi sayuran tertinggi di Kabupaten Bekasi. Pertimbangan lainnya memilih Desa Srimahi karena memiliki rumah tangga petani sayuran terbanyak menanam sayuran dibanding desa lain.

\begin{tabular}{l}
\multicolumn{2}{c}{ Penelitian didesain secara } \\
kuantitatif dengan metode \\
deskriptif. Data yang
\end{tabular}
merupakan data primer yang berasal dari pengisian kuesioner dan wawancara kepada responden. Selain itu, terdapat data sekunder yang bersumber dari berbagai lembaga atau instansi, buku, jurnal, skripsi, dan media informasi lainnya yang berhubungan dengan penelitian. 
Responden pada penelitian ini adalah ibu rumah tangga petani sayuran Desa Srimahi Kecamatan Tambun Utara Kabupaten Bekasi. Teknik pengambilan sampel dilakukan dengan cara simple random sampling. Populasi dalam penelitian yaitu rumah tangga petani di Desa Srimahi yang berjumlah 3.449 KK. Peneliti menggunakan rumus slovin untuk menentukan jumlah responden. Berdasarkan rumus slovin tersebut dengan nilai kritis atau batas ketelitian yang diambil sebanyak 12\%, maka didapati jumlah sampel yang diambil untuk dijadikan responden sebanyak 66 rumah tangga.

Analisis data dalam penelitian ini yaitu menggunakan analisis regresi logistik. Regresi logistik digunakan untuk menjelaskan hubungan antara variabel yang merupakan data dikotomik/biner dengan variabel bebas yang berupa data dalam skala interval atau kategorik dengan hanya mempunyai dua kategori saja, yaitu kategori yang menyatakan kejadian berhasil ( $\mathrm{Y}=1)$ dan kategori yang menyatakan kejadian gagal ( $Y=0)$ (Hosmer dan Lameshow, 2000).

Bentuk model regresi logistik dengan variabel prediktor i adalah sebagai berikut:

$\pi(x)=\frac{e(\beta 0+\beta 1 X 1+\beta 2 X 2+\cdots \beta i X i)}{1+e(\beta 0+\beta 1 X 1+\beta 2 X 2+\cdots \beta i X i)}$
Dengan menggunakan transformasi logit dari $\pi(\mathrm{x})$, maka model regresi fungsi logit dapat didefinisikan sebagai berikut:

$Y=\beta 0+\beta 1 X 1+\beta 2 X 2+\beta 3 X 3+\beta 4 X 4+$ $\beta 5 X 5+\beta 6 X 6+\beta 7 X 7+\varepsilon i$

Bentuk logit $\mathrm{Y}$ ini merupakan model logit, fungsi linear dalam parameter-parameternya, dan berada dalam jarak antara $-\infty$ sampai $+\infty$ tergantung dari variabel $\mathrm{X}$.

Keterangan:

$\mathrm{Y}=$ Jumlah Konsumsi Sayuran

$1=$ Jumlah konsumsi sayuran cukup

$0=$ Jumlah konsumsi sayuran kurang $\beta 0=$ Konstanta

$\beta=$ Koefisien regresi

X1 : Pendapatan Rumah Tangga

X2 : Jumlah Anggota Rumah Tangga

X3 : Pendidikan Ibu

X4 : Ketersediaan Sayur

X5 : Pengetahuan Gizi Ibu

X6 : Pekerjaan Ibu

$\varepsilon i=$ Standar error

\section{HASIL DAN PEMBAHASAN}

Desa Srimahi terletak di Kecamatan Tambun Utara, Kabupaten Bekasi, Provinsi Jawa Barat. Desa Srimahi memiliki luas wilayah 459,000 $\mathrm{Ha}$ dengan jarak tempuh ke ibu kota Kecamatan Tambun Utara $6.6 \mathrm{Km}$ dan 
ibu kota Kabupaten Bekasi $25 \mathrm{Km}$ secara ketinggian 25 mdpl. Desa Srimahi terdiri atas 3 dusun, $6 \mathrm{RW}$, dan 28 RT. Desa Srimahi memiliki batas-batas wilayah sebagai berikut:

a. Utara : Kecamatan Sukawangi

b. Selatan : Kecamatan Tambun Selatan

c. Barat : Desa Srijaya, Kecamatan Tambun Utara

d. Timur : Kecamatan Tambelang

Desa Srimahi merupakan daerah dengan ketinggian 0-115 mdpl dengan curah hujan $3200 \mathrm{~mm} /$ tahun, suhu ratarata harian adalah $280 \mathrm{C}-320 \mathrm{C}$ dan memiliki $\mathrm{pH}$ tanah antara 5.5 sampai 6.5. Desa ini memiliki luas wilayah sebesar 459,000 Ha yang terdiri atas $256,288 \mathrm{Ha}$ tanah sawah dan 202,712 Ha Tanah Darat. Jenis tanah di Desa Srimahi terbagi dua, yaitu bagian utara alluvial kelabu juga coklat, dan bagian selatan alluvial Glei Humus juga coklat. Pemanfaatan lahan di Desa Srimahi sebagian besar digunakan untuk lahan pertanian khususnya untuk perkebunan.

Faktor-faktor yang Mempengaruhi Pola Konsumsi Sayuran Rumah Tangga Petani di Desa Kepala Srimahi, Kecamatan Tambun Utara, Kabupaten Bekasi

Sebelum melakukan analisis regresi logistik, dilakukan terlebih dahulu uji asumsi yaitu uji multikolinieritas. Berdasarkan output SPSS, hasil uji multikolinieritas terlihat pada Tabel 1.

Tabel 1. Hasil Pengujian Multikolinearitas

\begin{tabular}{lcc}
\hline \multicolumn{1}{c}{ Variabel } & Tolerance & VIF \\
\hline Pendapatan & .940 & 1.064 \\
Jumlah Anggota & .968 & 1.034 \\
Keluarga & & \\
Pendidikan Ibu & .962 & 1.039 \\
Rumah Tangga & & \\
Ketersediaan Sayur & .963 & 1.038 \\
Pengetahuan Gizi & .940 & 1.063 \\
Ibu & & \\
Pekerjaan Ibu & .935 & 1.069 \\
Sumber: Output Software SPSS 2020 (Diolah)
\end{tabular}

Berdasarkan Tabel 1 dapat dilihat bahwa seluruh variabel independen memiliki nilai VIF (Variance Inflation Factor) tidak lebih dari 10, dan seluruh variabel independen memiliki nilai tolerance $>0.10$. Hal ini menunjukan bahwa data tidak terdapat kolinear antar variabel dalam model regresi logistik yang digunakan.

\section{Kelayakan Model Regresi}

Menilai kelayakan model regresi dapat dilakukan dengan melihat nilai signifikan pada tabel Hosmer and Lemeshow Goodness of Fit. Model dapat dikatakan mampu memprediksi nilai observasi dan cocok dengan data observasinya apabila nilai Chi-square $>$ 0,05. Hasil uji kelayakan model regresi terlihat pada Tabel 2 . 
Tabel 2. Hasil Uji Kelayakan Model Regresi

\begin{tabular}{ccc}
\hline Chi-square & df & Sig. \\
\hline 4.501 & 7 & .721 \\
\hline Sumber: Output Software SPSS 2020 (Diolah)
\end{tabular}

Pada Tabel 2, diperoleh nilai signifikan hasil uji kelayakan model sebesar 0,721 dengan nilai signifikan > 0,05 menunjukkan bahwa model regresi yang terbentuk mampu memprediksi nilai observasi dengan baik dan cocok dengan data observasinya, sehingga model regresi yang dipergunakan dalam penelitian ini layak dipakai untuk analisis selanjutnya, hal ini karena karena tidak ada perbedaan yang nyata antara klasifikasi yang diprediksi dengan klasifikasi yang diamati.

Dalam penelitian ini, terdapat 3 faktor yang mempengaruhi pola konsumsi sayuran rumah tangga petani di Desa Srimahi, yaitu tingkat pendidikan ibu rumah tangga, pengetahuan gizi ibu dan pekerjaan ibu. Setelah diuji dengan menggunakan SPSS diketahui bahwa pengaruh variabel bebas (tingkat pendidikan ibu rumah tangga, pengetahuan gizi ibu dan pekerjaan ibu) terhadap variabel terikat (pola konsumsi sayuran rumah tangga) seperti terlihat pada Tabel 3.

Tabel 3. Hasil Analisis Regresi Faktor-Faktor yang Mempengaruhi Pola Konsumsi Sayur Rumah Tangga Petani di Desa Kepala Srimahi Kecamatan Tambun Utara, Kabupaten Bekasi

\begin{tabular}{lclc}
\hline \multicolumn{1}{c}{ Variabel } & B & Sig & Exp (B) \\
\hline Pendapatan & -1.125 & .175 & .325 \\
Jumlah anggota keluarga & .937 & .186 & 2.552 \\
Pendidikan ibu & 1.508 & $.027^{*}$ & 4.517 \\
Ketersediaan sayur & .278 & .695 & 1.321 \\
Pengetahuan gizi ibu & 1.380 & $.040^{*}$ & 3.976 \\
Pekerjaan ibu & 1.843 & $.005^{*}$ & 6.313 \\
Constant & -3.044 & .002 & .048 \\
\hline R Square & $\mathbf{. 4 1 6}$ & \\
\hline Sumber: Output Software SPSS 2020 (Diolah) & &
\end{tabular}

Sumber: Output Software SPSS 2020 (Diolah)

Berdasarkan Tabel 3, diperoleh nilai Negelkerke R Square dalam model regresi yaitu sebesar 0,416 yang berarti besar variansi variabel jumlah konsumsi sayur yang dapat dijelaskan oleh variabel pendapatan, jumlah anggota keluarga, pendidikan ibu, ketersediaan sayur, pengetahuan dan pekerjaan adalah sebesar $\quad 41,6 \%, \quad$ sedangkan $\quad 58,4 \%$ dipengaruhi oleh faktor lain di luar model seperti preferensi konsumsi sayur, pengaruh media sosial, umur, sikap, gaya hidup, dan lain-lain. Nilai (R2) ini masih lebih baik dari R2 pada penelitian Dian (2019) yang menjadi rujukan dalam penelitian ini, yaitu sebesar 0,376 atau $37,6 \%$. 
Berdasarkan hasil penelitian, variabel pendapatan (X1) berpengaruh negatif dan tidak ada hubungan yang signifikan terhadap variabel konsumsi sayuran (Y). Dari hasil penelitian dapat ditunjukkan dengan nilai signifikan sebesar $0,175>0,05$. Artinya pendapatan tidak berpengaruh terhadap konsumsi sayuran pada rumah tangga petani sayuran di Desa Srimahi, Kecamatan Tambun Utara, Kabupaten Bekasi. Berdasarkan hasil wawancara dengan responden, pendapatan rumah tangga tidak berpengaruh terhadap konsumsi sayuran dikarenakan mereka sudah terbiasa mengonsumsi sayuran sehari-hari walaupun dengan jumlah yang masih kurang memenuhi standar kecukupan konsumsi sayuran sehari-hari. Hasil penelitian ini sejalan dengan penelitian yang dilakukan oleh Dian (2019) bahwa pendapatan tidak berpengaruh secara signifikan terhadap konsumsi sayuran pada rumah tangga petani.

Dalam penelitian ini, variabel jumlah anggota keluarga (X2) berpengaruh negatif dan tidak ada hubungan yang signifikan terhadap variabel konsumsi sayuran (Y). Dari hasil penelitian dapat ditunjukkan dengan nilai signifikan sebesar $0,186>0,05$. Artinya jumlah anggota keluarga tidak berpengaruh terhadap konsumsi sayuran pada rumah tangga petani sayuran di Desa Srimahi, Kecamatan Tambun Utara, Kabupaten Bekasi. Hasil penelitian ini sejalan dengan penelitian yang dilakukan oleh Dian (2019) bahwa jumlah anggota berpengaruh secara signifikan terhadap konsumsi sayuran pada rumah tangga petani dengan nilai signifikansi sebesar $0,817>0,05$. Windi (2016) menyatakan bahwa tidak berhubungannya jumlah anggota terhadap konsumsi sayuran karena bukan hanya faktor jumlah anggota, melainkan terdapat faktor ketersediaan sayur.

Dalam penelitian ini, variabel pendidikan ibu rumah tangga (X3) berpengaruh positif dan ada hubungan yang signifikan terhadap variabel konsumsi sayuran (Y). Dari hasil penelitian dapat ditunjukkan dengan nilai signifikan sebesar $0,027<0,05$. Artinya pendidikan $\mathrm{ibu}$ rumah tangga berpengaruh terhadap konsumsi sayuran pada rumah tangga petani sayuran di Desa Srimahi, Kecamatan Tambun Utara, Kabupaten Bekasi. Rendahnya tingkat pendidikan ibu rumah tangga menyebabkan kurangnya konsumsi sayuran pada rumah tangga di Desa Srimahi. Hasil penelitian ini sejalan dengan penelitian yang dilakukan oleh 
Dian (2019) bahwa pendidikan ibu rumah tangga berpengaruh secara signifikan terhadap konsumsi sayuran pada rumah tangga petani.

Dalam penelitian ini, variabel ketersediaan sayur (X4) berpengaruh negatif dan tidak ada hubungan yang signifikan terhadap variabel konsumsi sayuran (Y). Dari hasil penelitian dapat ditunjukkan dengan nilai signifikan sebesar 0,695 $>0,05$. Artinya ketersediaan sayur tidak berpengaruh terhadap konsumsi sayuran pada rumah tangga petani sayuran di Desa Srimahi, Kecamatan Tambun Utara, Kabupaten Bekasi. Hal sejalan dengan pendapat Suhardjo (2006) dimana seorang petani akan lebih mudah mendapatkan sayur, karena tempat tinggal yang dekat dengan areal pertanian. Dan seseorang yang tinggal di daerah perkotaan akan lebih sedikit akses untuk mendapatkan bahan makanan yang segar seperti sayur karena jauh dari areal pertanian.

Dalam penelitian ini, variabel pengetahuan gizi ibu (X5) berpengaruh positif dan memiliki hubungan yang signifikan terhadap variabel konsumsi sayuran (Y). Dari hasil penelitian dapat ditunjukkan dengan nilai signifikan sebesar $0,040<0,05$. Artinya pengetahuan gizi ibu berpengaruh

terhadap konsumsi sayuran pada rumah tangga petani sayuran di Desa Srimahi, Kecamatan Tambun Utara, Kabupaten Bekasi. Hasil penelitian ini sejalan dengan penelitian yang dilakukan oleh Dian (2019) bahwa pengetahuan gizi ibu berpengaruh secara signifikan terhadap konsumsi sayuran pada rumah tangga petani.

Berdasarkan hasil penelitian di Desa Srimahi diketahui bahwa sebagian besar ibu rumah tangga memiliki pekerjaan atau bekerja. Dari hasil uji statistik, variabel ketersediaan sayur (X6) berpengaruh positif dan ada hubungan yang signifikan terhadap variabel konsumsi sayuran (Y). Dari hasil penelitian dapat ditunjukkan dengan nilai signifikan sebesar $0,005<0,05$. Artinya pekerjaan ibu berpengaruh terhadap konsumsi sayuran pada rumah tangga petani sayuran di Desa Srimahi, Kecamatan Tambun Utara, Kabupaten Bekasi. Apabila ibu sibuk bekerja, maka mereka tidak akan bisa mengontrol makanan atau jenis pangan yang dikonsumsi oleh keluarganya (Khomsan, 2003). 


\section{KESIMPULAN DAN SARAN}

\section{Kesimpulan}

Berdasarkan pembahasan data hasil penelitian yang telah dilakukan, dapat disimpulkan adalah faktor-faktor yang mempengaruhi pola konsumsi sayur pada rumah tangga petani sayur di Desa Srimahi Kecamatan Tambun Utara Kabupaten Bekasi adalah pendidikan ibu rumah tangga, pengetahuan gizi ibu, dan pekerjaan ibu rumah tangga. Faktor pekerjaan ibu memiliki hubungan atau signifikansi yang sangat tinggi yaitu sebesar $0,005<0,05$.

\section{Saran}

Berdasarkan hasil penelitian yang telah disimpulkan, terdapat temuan yang dapat dijadikan saran, yaitu bagi peneliti selanjutnya diharapkan dapat melakukan penelitian sejenis yaitu mengenai pola konsumsi sayuran pada rumah tangga petani dengan menambahkan faktorfaktor lain seperti preferensi konsumsi sayur, pengaruh media sosial, umur, sikap, gaya hidup, dan lain-lain sebagai variabelnya.

\section{DAFTAR PUSTAKA}

Hosmer, d. W., \& lameshow, s. (2000). Applied logistic regression. New york: a wiley interscience publication.
Hutauruk, M. R. 2020. Pengaruh Pandemi Covid-19 Terhadap Faktor Yang Menentukan Perilaku Konsumen Untuk Membeli Barang Kebutuhan Pokok Di Samarinda. Jurnal Riset Inossa, 2(1), 1-15.

Murdiati, A., Amaliah. 2013. Panduan Penyiapan Pangan Sehat untuk Semua. Kencana Prenadamedia Group. Jakarta

Winarto,W.P. 2014. Memanfaatkan Tanaman Sayur Untuk Mengatasi Aneka Penyakit. Tanggerang: AgroMedia Pustaka.

Rachman HPS, Ariani M. 2008. Penganekaragaman konsumsi pangan di Indonesia: permasalahan dan implikasi untuk kebijakan dan program. AKP. 6(2):140-154.

Dian Widya Putri. 2019. Pengambilan Keputusan Dalam Pemilihan Sayuran Dan Pola Konsumsi Sayuran Rumah Tangga Petani Sayuran Di Desa Gisting Atas Kecamatan Gisting Kabupaten Tanggamus. Skripsi. Lampung : Fakultas Pertanian, Universitas Lampung.

Windi Kharisma Putra. 2016. FaktorFaktor Yang Berhubungan Dengan Konsumsi Buah Dan Sayur Pada Anak Sekolah Dasar. Skripsi. Semarang: Fakultas Ilmu Keolahragaan Universitas Negeri Semarang.

Suhardjo, dkk. 2006. Pangan, Gizi dan Pertanian. Jakarta: UI Press.

Khomsan, A. 2003.Pangan dan Gizi untuk Kesehatan.PT. Rajagrafindo Persada. Jakarta. 